\title{
PENGARUH BOBOT LAHIR DENGAN PENAMPILAN ANAK BABI SAMPAI DISAPIH
}

\author{
Marfiane M. Nangoy*, M.T. Lapian**, M. Najoan***, J. E. M. Soputan**
}

\section{Fakultas Peternakan Universitas Sam Ratulangi, Manado 95115}

\begin{abstract}
ABSTRAK
Penelitian ini bertujuan untuk mengetahui pengaruh bobot lahir terhadap penampilan anak babi sampai disapih. Dalam penelitian ini menggunakan metode observasi. Hasil atau data yang di peroleh dalam penelitian ini, anak babi dari masing-masing induk dibagi menjadi 3 bagian yaitu: tinggi, sedang, rendah. Pengambilan data dilaksanakan pada waktu anak babi baru dilahirkan, anak babi berumur 1 minggu sampai pada waktu penyapihan. Peubah yang diamati dalam penelitian ini adalah bobot lahir (BL) anak babi per ekor, pertambahan bobot badan (PBB), bobot sapih, dan mortalitas (MRTA) anak babi prasapih (\%). Data yang diperoleh dianalisis dan disajikan secara deskriptif, yaitu penguraian dan penjelasan mengenai gambaran-gambaran umum dari hasil pengamatan secara langsung. Berdasarkan hasil penelitian dapat disimpulkan bahwa bobot lahir anak babi, menentukan seberapa besar litter size, bobot sapih, PBB, dan mortalitas. Semakin besar bobot lahir semakin besar kemungkinan memperoleh bobot sapih yang tinggi seperti dalam penelitian ini bobot lahir tertinggi yaitu $1.64 \mathrm{~kg}$ setelah di sapih mencapai bobot 7.54 $\mathrm{kg}$.
\end{abstract}

Kata kunci: Bobot lahir, anak babi, disapih

\section{ABSTRACT \\ THE EFFECT OF BIRTH WEIGHT WITH THE APPEARANCE OF THE PIGLETS UNTIL WEANING. The purpose of}

\footnotetext{
*Alumni Fakultas Peternakan Unsrat

** Jurusan Produksi Ternak

*** Jurusan Nutrisi dan Makanan Ternak
}

this research is to determine the corellation of birth weight with the appearance of the piglets until weaning. This research used the method of observation. Results or data obtained in this research, piglets from each parent is divided into 3 categories: high, medium, low. Retrieval of data held on a new born piglets, piglets aged 1 week until the time of weaning. Parameters observed in this research is the birth weight of piglets per head, body weight gain, the weight of piglets, and mortality (MRTA) piglets before weaned (\%). Data were analyzed and presented descriptively, which is describing and explaining the general picture of direct observation. Based on the results of this research we concluded that litter size piglets, determines how high the birth weight, weaning weight, body weight gain, and mortality. The greater the birth weight more likely to obtain a high weaning weight as in this research the highest birth weight is 1.64 $\mathrm{kg}$ after weaning reached $7.54 \mathrm{~kg}$.

Keywords: Birth Weight, Piglets, Weaning

\section{PENDAHULUAN}

Ternak babi adalah salah satu ternak yang dapat menunjang kebutuhan masyarakat akan protein hewani, walaupun ternak babi ini hanya bisa di konsumsi oleh sebagian dari masyarakat, oleh karena itu produksi ternak babi kususnya di Sulawesi utara perlu di tingkatkan. 
Ternak babi merupakan komoditas yang memiliki potensi besar untuk dikembangkan karena mempunyai sifatsifat menguntungkan, yaitu mampu mengubah bahan makanan menjadi efisien, mempunyai siklus reproduksi yang pendek, dan bersifat prolific (beranak banyak) berkisar 8-14 ekor dalam setiap kelahiran, dengan rata-rata dua kali beranak pertahunnya, lebih cepat tumbuh, dan cepat dewasa. Sihombing (2006) ternak babi juga merupakan ternak pemakan segala yang termasuk di dalamnya limbah pertanian, limbah industri, dan lain sebagainya yang tidak lagi digunakan oleh jenis ternak lain.

Ternak babi juga mempunyai potensi besar dalam penyediaan daging secara nasional, ditinjau dari jumlah populasi ternak babi di Indonesia sebesar 6.710.758 ekor dengan jumlah pemotongan 3.092.420 ekor dan produksi daging sebanyak 225.905 ton pada tahun 2007. Ternak babi mempunyai sumbangan produksi daging sebesar 10,93\%.Sulawesi Utara merupakan daerah yang memproduksi daging babi keempat terbanyak Setelah Bali, Sumatra Utara, dan NTT.Berdasarkan statistik peternakan dan kesehatan hewan (2011), total pemotongan ternak babi di Sulawesi Utara adalah $12,15 \%$ dari total pemotongan ternak babi di Indonesia.
Ternak babi yang dilahirkan mempunyai bobot badan yang tidak merata atau tidak seragam, dengan demikian anak babi yang mempunyai bobot badan rendah akan mempengaruhi penampilan ternak babi sampai pada penyapihan.

Pond and maner (1974) menyatakan, anak babi yang mempunyai bobot badan rendah erat hubungan dengan ketahanan hidup.Penampilan ternak babi yang baik akan meningkatkan produktivitas ternak dan sebaliknya penampilan produksi yang buruk akan menurunkan produktivitas ternak. Anak babi yang lahir umumnya mempunyai bobot badan tidak seragam yaitu ada yang mempunyai bobot badan yang tinggi, ada yang rendah yaitu lebih kecil satu kg sampai lebih besar dua kg hal ini dapat mempengaruhi ketahanan hidup anak babi. Anak babi dilahirkan dengan bobot badan yang tinggi dapat kesempatan hidup sampai di sapih. Sebaliknya yang mempunyai bobot badan rendah tidak akan bertahan hidup. Hal ini mungkin di sebabkan persaingan dalam menyusu dari anak babi itu sendiri. Anak babi yang mempunyai bobot badan tinggi lebih mendapatkan kesempatan untuk memperoleh air susu dari pada yang bobot badan rendah.

Pertambahan berat badan (PBB) perlu kita ketahui karena pertambahan bobot badan dari anak babi sangat 
berpengaruh pada waktu akan di sapih. Biasanya faktor yang mempengaruhi pertambahan borot badan adalah produksi air susu induk, jumlah anak yang dilahirkan, pemeliharaan induk yang sedang menyusui, kualitas ransum yang diberikan, dan keturunan/genetik dari ternak babi itu sendiri.

Pond and Maner (1974) menyatakan, jumlah anak babi sekelahiran (litter size) yang tinggi dengan bobot lahir yang rendah juga akan mempengaruhi mortalitas anak babi selama menyusu. Perkembangan juga anak babi sangat tergantung pada kemampuan anak babi mengkonsumsi air susu pada induk babi selama laktasi.

Bobot sapih tergantung pada bobot lahir karena kondisi dari anak babi sangat di pengaruhi oleh pertumbuhan prenatal Dziuk (1992), termasuk perubahan biokimia sebelum implantasi embrio oleh estradiol dan progesteron. Bobot sapi juga merupakan indikator dari produksi air susu induk babi dan kemampuan bertumbuh anak babi.

Mortalitas anak babi sangat mempengaruhi berkembangnya suatu usaha peternakan, penampilan produksi anak babi tidak lari dari angka mortalitas, baik pada waktu ternak baru di lahirkan sampai pada saat anak babi akan di sapih.

Hasil uraian di atas bertujuan untuk mengetahui sampai sejauh mana bobot lahir dengan penampilan anak babi pada saat di lahirkan sampai pada waktu penyapihan. Berdasarkan hasil uraian diatas maka telah di lakukan penelitian untuk mengetahui sampai sejauh mana pengaruh bobot lahir terhadap penampilan anak babi sampai di sapih.

\section{MATERI DAN METODE PENELITIAN}

Penelitian ini telah dilaksanakan di Peternakan Bpk. Ronal Kalalo yang bertempat di Kelurahan Wailan, Kecamatan Tomohon Barat, Kota Tomohon, Provinsi Sulawesi Utara, mulai dari bulan juni tanggal 5 sampai bulan juli tanggal 5tahun 2014. Ternak yang digunakan dalam penelitian ini adalah babi induk Hasil Persilangan keturunan Landrace,Yorkshire, dan Duroc sebanyak 8 ekor dengan bobot badan berkisar antara 100-108 kg. setelah induk beranak, anak babi tersebut di jadikan bahan untuk di teliti. Ransum yang digunakan selama penelitian disesuaikan dengan ransum yang digunakan di perusahaan, yaitu: kosentrat $75 \%$ dan jagung $25 \%$.

Kandang yang akan di gunakan dalam penelitian ini adalah kandang babi bunting, kandang induk babi beranak. Kandang untuk babi bunting merupakan kandang yang berukuran 2,5 x $2 \mathrm{~m}$, kandang untuk babi beranak dan menyusui 
masing-masing kandang individu yang berukuran $3 \times 3 \mathrm{~m}$ yang di dalamnya di lengkapi dengan box tempat anak babi, berukuran $1 \times 1,5 \mathrm{~m}$ dan diberi alat penghangat/lampu pijar, timbangan gantung, cat, dan karung plastik untuk menimbang anak babi yang baru di lahirkan.

\section{Prosedur Pengamatan}

1. Setelah anak babi dilahirkan di timbang, untuk mengetahui bobot lahir (BL)

2. Anak yang sudah ditimbang kemudian diberi tanda, agar mudah dalam penimbangan.

3. Anak babi di timbang kembali setelah berusia 1 minggu, 2 minggu, 3 minggu, dan 4 minggu.

4. Penimbangan minggu pertama, kedua, ketiga dan keempat untuk mengetahui pertambahan bobot badan (PBB) anak babi, dan bobot badan pada minggu ke empat adalah bobot sapih.

Hasil bobot badan anak babi dari masing-masing induk di kelompokan menjadi 3 kategori yaitu : tinggi, sedang dan rendah. Pengambilan data di lakukan pada waktu anak babi di lahirkan, anak babi berumur 1 minggu, sampai di sapih. Cara pengambilan data yaitu anak babi di puasakan selama 4 jam mulai jam 4 pagi kemudian anak babi, ditimbang untuk mengetahui bobot badan selesai puasa, setelah itu anak babi dibiarkan menyusu pada induk selama 60 menit setelah selesai menyusu, anak babi di timbang kembali untuk mengetahui pertambahan bobot badan (PBB).

1. Bobot lahir anak babi, bobot lahir anak babi per ekor (BLPL) (kg/e), diperoleh dengan cara menimbang semua anak babi yang hidup lahir dari seperindukan.

2. Pertambahan bobot badan (PBB) (per ekor/minggu), diperoleh berat akhir dikurangi berat awal.

3. Bobot sapi anak babi, diperoleh dari berat akhir selama penelitian.

4. Mortalitas (MRTA) anak babi prasapih (\%) diperoleh dengan menghitung jumlah anak yang mati dari seperindukan selama menyusui (28 hari), kemudian dibagi dengan jumlah anak yang lahir hidup dan dikalikan dengan 100\% (persentase mortalitas).

Data yang diperoleh dianalisis dan disajikan secara deskriptif, yaitu penguraian dan penjelasan mengenai gambaran-gambaran umum dari hasil pengamatan secara langsung. 
HASIL DAN PEMBAHASAN

\section{Liter Size dan Bobot Lahir Anak Babi dari Beberapa Persilangan Induk (Kg)}

Litter size dan bobot lahir mulai yang paling tinggi sampai paling rendah yaitu: litter size induk 1 dan 2 : 14 anak babi, litter size induk ke $6: 12$ anak babi, induk 5 dan 8 yaitu 10 anak babi, dan induk 3, 4 dan 7 yaitu 8 ekor. Litter size dan bobot lahir anak babi dapat dilihat pada Tabel 1.

Berdasarkan hasil penelitian litter size anak babi dari induk 1 dan 2, mempunyai litter size yang sama yaitu 14 anak babi dari masing-masing induk. Berbeda dengan induk 6 mempunyai litter size 12, dan induk 5 dan 8 memiliki kesamaan litter size yaitu 10 ekor anak babi dari masing-masing induk.Sedangkan induk 3, 4, dan 7, memiliki litter size terendah yaitu masingmasing induk mempunyai litter size 8 ekor anak babi. Dari setiap induk anak babi memiliki rataan bobot lahir yang bervariasi, antara lain induk 1, 2, 5, dan 6, memiliki rataan bobot lahir $(1,34 \mathrm{~kg}),(1,41 \mathrm{~kg}),(1,59$ $\mathrm{kg})$, dan $(1,47 \mathrm{~kg})$.

Tabel 1.Liter size dan bobot lahir anak babi dari beberapa persilangan induk (Kg)

\begin{tabular}{ccccccccc}
\hline \multirow{2}{*}{$\begin{array}{c}\text { Litter } \\
\text { size }\end{array}$} & 1 & 2 & 3 & 4 & 5 & 6 & 7 & 8 \\
\cline { 2 - 8 } 1 & 1.6 & 1.6 & 1.7 & 1.7 & 1.7 & 1.7 & 1.7 & 1.7 \\
2 & 1.5 & 1.7 & 1.6 & 1.7 & 1.7 & 1.7 & 1.6 & 1.6 \\
3 & 1.5 & 1.6 & 1.7 & 1.7 & 1.6 & 1.4 & 1.6 & 1.6 \\
4 & 1.5 & 1.5 & 1.6 & 1.6 & 1.6 & 1.5 & 1.6 & 1.7 \\
5 & 1.4 & 1.4 & 1.6 & 1.6 & 1.7 & 1.5 & 1.7 & 1.7 \\
6 & 1.4 & 1.5 & 1.6 & 1.6 & 1.6 & 1.4 & 1.7 & 1.6 \\
7 & 1.3 & 1.5 & 1.7 & 1.7 & 1.6 & 1.5 & 1.7 & 1.6 \\
8 & 1.2 & 1.5 & 1.5 & 1.5 & 1.5 & 1.5 & 1.5 & 1.7 \\
9 & 1.1 & 1.3 & & & 1.4 & 1.5 & & 1.5 \\
10 & 1.2 & 1.2 & & & 1.5 & 1.4 & & 1.5 \\
11 & 1.3 & 1.2 & & & & 1.3 & & \\
12 & 1.3 & 1.3 & & & & & & \\
13 & 1.2 & 1.3 & & & & & & \\
14 & 1.2 & 1.2 & & & & & & \\
\hline Rataan & 1.34 & 1.41 & 1.63 & 1.64 & 1.59 & 1.47 & 1.64 & \\
\hline & & & & & & & & \\
\hline
\end{tabular}


Bobot lahir anak babi dari induk 1, 2, 5, dan 6 , sangat redah bila di bandingkan dengan induk 3, 4, 7, dan 8 lebih tinggi yaitu $(1,63$ $\mathrm{kg}),(1,64 \mathrm{~kg}),(1,64 \mathrm{~kg}),(1,62 \mathrm{~kg})$.

Bobot lahir anak babi berhubungan dengan litter size anak babi, berdasarkan hasil penelitian dengan litter size yang kecil mempengaruhi bobot lahir anak babi. Anak babi yang litter size kecil memiliki bobot lahir yang tinggi, sebaliknya dengan bobot lahir rendah memiliki litter size yang tinggi. Hasil penelitian ini sesuai dengan pendapat dari Gordon, (2008) menyatakan jumlah anak sekelahiran sedikit akanmeningkatkan bobot lahir, begitu juga sebaliknya anak babi yang dilahirkan dalam jumlah yang banyak akan menurunkan bobot lahir.

Toelihere (1985) menyatakan bahwa besarnya litter size lahir bervariasi menurut tiap masa kelahiran pada induk yang sama. Hal ini dipengaruhi oleh umur, varitas, lingkungan, dan kesanggupan reproduksi tiap induk ternak babi. Semakin sering induk beranak, semakin besar litter sizelahir, dan biasanya mencapai puncak pada kelahiran ketiga atau keempat kemudian masa stabil sampai kelahiran keenam atau ketujuh, selanjutnya terjadi penurunan secara bertahap. De Borsotti et al (1982) menyatakan bahwa bobot lahir anak babi dipengaruhi oleh beberapa hal, antara lain frekuensi induk babi beranak (parity), umur induk, bangsa induk, dan jumlah anak babi seperindukan pada waktu lahir.

\section{Persentase Bobot Lahir Anak Babi}

Hasil penelitian persentase bobot lahir terlihat pada Tabel 2. Persentase bobot lahir dari anak babi dalampenelitian ini bervariasi yaitu $1,1-1,7 \mathrm{~kg}$. Persentase bobot lahir dapat dilihat pada tabel 2 . Bobot lahir anak babi di bagi menjadi 3 kategori atau 3 kelompok yaitu BL tinggi (1,6-1,7), BL sedang $(1,4-1,5)$, dan BL rendah $(1,1-1,3)$. Persentase bobot lahir anak babi terdiri dari 8 induk babi yang memiliki bobot lahir anak babi yang berbeda, dari masing-masing induk. Berdasarkan hasil penelitian rataan persentase bobot lahir anak babi dari induk 1-8 persentase yang tertinggi berada pada BL tinggi yaitu $56,80 \%$ persentase sedang $28,61 \%$, paling rendah terdapat pada $\mathrm{BL}$ rendah 14,58\%. Dari tabel 2 terlihat bahwa, periode bobot lahir dari anak babi dalam penelitian bervariasi yaitu 1,1-1,7 $\mathrm{kg}$. Bobot lahir anak babi di bagi menjadi 3 kategori tinggi, sedang dan rendah.

Hal ini sesuai dengan pendapat dari Sihombing (1997) bahwa bobot lahir anak bervariasi antara 1.09-1.77 kg. De Borsotti et al. (1982) menyatakan bahwa bobot lahir anak babi dipengaruhi oleh beberapa hal, antara lain frekuensi induk babi beranak (parity), umur induk, bangsa induk, dan jumlah anak babi seperindukan pada waktu lahir. Hal ini sama dengan pernyataan dengan Pardosi (2004) menyatakan 
Tabel 2. Persentase bobot lahir anak babi dalam kategori dari masing-masing Induk

Presentase Bobot Lahir Anak Babi dari Kategori Tinggi, Sedang, dan Rendah.

\begin{tabular}{ccccc}
\hline INDUK & Rataan Sd & $\begin{array}{c}\text { Tinggi } \\
(1.6-1.7)\end{array}$ & $\begin{array}{c}\text { Sedang } \\
(1,4-1,5)\end{array}$ & $\begin{array}{c}\text { Rendah } \\
(1,1-1,3)\end{array}$ \\
\hline 1 & $1.34 \pm 0.15$ & 7.14 & 35.71 & 57.14 \\
2 & $1.41 \pm 0.17$ & 21.42 & 35.71 & 42.85 \\
3 & $1.41 \pm 0.07$ & 87.50 & 12.50 & 0 \\
4 & $1.64 \pm 0.07$ & 87.50 & 12.50 & 0 \\
5 & $1.59 \pm 0.11$ & 66.66 & 33.33 & 0 \\
6 & $1.47 \pm 0.14$ & 16.66 & 66.66 & 16.66 \\
7 & $1.63 \pm 0.07$ & 87.50 & 12.50 & 0 \\
8 & $1.62 \pm 0.08$ & 80 & 20 & 0 \\
\hline Rataan & & 56.80 & 28.61 & 14.58 \\
\hline
\end{tabular}

beberapa sifat penting pada ternak babi adalah jumlah anak yang dilahirkan per induk perkelahiran, bobot lahir, jumlah anak lepas sapih, dan yang sangat mempengaruhi yaitu perkawinan antara bangsa dan frekuensi beranak dari induk babi (Parity) atau paritas. Paritas juga berhubungan dengan umur induk saat melahirkan anak maupun jumlah anak yang dilahirkan litter sizeakan meningkat jika induk memiliki paritas tinggi.

Jumlah anak per kelahiran di sebabkan oleh beberapa faktor Gordon (2008), Genetik, stres, dan fertilitas pejantan. Lawlor dan Lynch (2007) menambahkan bahwa paritas pertama pada induk akan menghasilkan anak babi yang lebih sedikit jika di bandingkan pada kelahiran berikutnya, jumlah anak babi yang dilahirkan akan meningkat seiring dengan seringnya induk tersebut mengalami paritas dan di harapkan anak babi dalam sekelahiran menghasikan performans yang lebih baik bila di bandingkan dengan induk yang hanya sekali mengalami paritas. Namun tiap kali paritas induk akan menghasilkan variasi bobot lahir anak babi, dan variasi anak babi sangat beragam karena dalam sekelahiran, induk dapat menghasilkan anak babi 6-12 ekor.

Gordon (2008) juga menyatakan jumlah anak sekelahiran sedikit akanmeningkatkan bobot lahir, begitu juga sebaliknya anak babi yang dilahirkan dalam jumlah yang banyak akan menurunkan bobot lahir. 


\section{Rataan Pertambahan Bobot Badan (PBB) Anak Babi Per Induk Per Minggu}

Dari hasil pengukuran rataan $\mathrm{PBB}$ anak babi per induk minggu 1 sampai minggu ke 4 dapat dilihat pada Tabel 3. Berdasarkan hasil penelitian,Pertambahan BobotBadan (PBB) anak babi meningkat pada minggu ke 2 dengan rataan PBB $1.44 \mathrm{Kg} / \mathrm{Minggu}$. Pertambahan bobot badan (PBB) per induk per minggu anak babi selama menyusu diperoleh dari selisih bobot badan anak babi saat lahir dan bobot badan anak babi pada saat disapih, yaitu pada hari ke-28. Pertambahan bobot badan anak babi menyusu bergatung pada kuantitas air susu yang diperoleh dari induknya selama masa laktasi.

Pertambahan bobot badan anak babi prapenyapihan bergantung pada bobot lahir anak babi dan produksi air susu induk babi, dan kemampuan anak babi untuk mengkonsumsi air susu. Dari table 3, dapat dilihat bahwa induk 7 memiliki PBB yang tinggi pada minggu ke 4, sedangkan yang terendah itu pada induk 1, 2, 3, 4, 5, 6, dan 8. Secara keseluruhan dapat dilihat rataan PBB dari minggu 1 sampai minggu ke 4 adalah yang paling tertinggi itu pada minggu ke 2 dengan rataan PBB (1.44), berdasarkan hasil penelitian rataan $\mathrm{PBB}$ yang paling rendah pada minggu 4 dengan rataan $\mathrm{PBB}(0.92)$.

Anggorodi (1994) menyatakan pertumbuhan anak sebelum sapih dipengaruhi oleh faktor genetik, bobot lahir, litter size lahir, produksi air susu, perawatan, dan umur induk.

Tabel 3. Rataan PBB Anak Babi Per Induk Per Minggu (Kg)

\begin{tabular}{ccccc}
\hline NO & $\begin{array}{c}\text { PBB } \\
\text { Minggu I }\end{array}$ & $\begin{array}{c}\text { PBB } \\
\text { Minggu 2 }\end{array}$ & $\begin{array}{c}\text { PBB } \\
\text { Minggu 3 }\end{array}$ & $\begin{array}{c}\text { PBB } \\
\text { Minggu 4 }\end{array}$ \\
\hline 1 & 1.12 & 0.93 & 0.66 & 0.80 \\
2 & 1.08 & 1.15 & 1.84 & 0.88 \\
3 & 1.36 & 2.01 & 1.30 & 0.85 \\
4 & 1.15 & 1.19 & 1.01 & 0.94 \\
5 & 1.11 & 2.43 & 1.19 & 0.42 \\
6 & 1.09 & 1.52 & 1.36 & 0.82 \\
7 & 1.15 & 1.15 & 1.64 & 1.96 \\
8 & 1.14 & 1.14 & 0.57 & 0.69 \\
\hline Rataan & 1.15 & 1.44 & 1.20 & 0.92 \\
\hline
\end{tabular}


Menurut Sihombing (1997) dan Anggorodi (1994) laju pertumbuhan dari lahir sampai disapih sebagian besar dipengaruhi oleh jumlah susu yang dihasilkan induk dan dipengaruhi pula oleh kesehatan individu.

\section{Rataan PBB Anak babi Berdasarkan Kategori Bobot Lahir Tinggi, Sedang dan Rendah}

Hasil penelitian rataan PBB yang di bagi menjadi 3 Kategori yaitu Bobot Lahir Tinggi, Bobot Lahir Sedang, dan Bobot Lahir Rendah dapat dilihat pada Tabel 4.
Hasil penelitian ini menunjukkan bahwa rataan $\mathrm{PBB}$ dari anak babi pada BLT 6,52 lebih tinggi di bandingkan dengan BLS 5,96, dan BLR.5,36. PBB anak babi dipengaruhi oleh berbagai faktor, diantaranya umur, nutrisi, lingkungan, berat lahir dan penyakit.Anggorodi (1979) menambahkan bahwa pertumbuhan anak babi sebelum disapih dipengaruhi oleh genetik, bobot lahir, litter size lahir, produksi air susu induk, dan umur induk.

Tabel 4. Rataan PBB anak babi dari kategori tinggi, sedang dan rendah, setelah di sapih

\begin{tabular}{cc}
\hline Kategori Bobot Lahir & Rataan dan Sd PBB \\
\hline BLT & $6.52 \pm 0.05$ \\
BLS & $5.96 \pm 0.04$ \\
BLR & $5.36 \pm 0.06$ \\
\hline
\end{tabular}

Tabel 5. Rataan Bobot Sapih Anak Babi Per Ekor dari Masing-Masing induk

\begin{tabular}{lcc}
\hline NO & Rataan Bobot Lahir & Rataan Bobot Sapih \\
\hline 1 & 1.34 & 4.90 \\
2 & 1.41 & 6.36 \\
3 & 1.41 & 6.93 \\
4 & 1.64 & 5.93 \\
5 & 1.59 & 6.74 \\
6 & 1.47 & 6.26 \\
7 & 1.64 & 7.54 \\
8 & 1.62 & 5.15 \\
\hline
\end{tabular}




\section{Rataan Bobot Sapih Anak Babi di Bandingkan Dengan Rataan Bobot Lahir}

Hasil pengamatan rataan bobot lahir dan rataan bobot sapih dapat dilihat pada Tabel 5. Bobot sapih anak babi adalah tahap pertumbuhan hewan atau ternak mamalia ketika tidak lagi bergantung pada air susu induknya dan mulai mengkonsumsi ransum padat dan cair (Inglis, 1980). Rataan bobot sapih per ekor dari masing-masing induk bervariasi yaitu pada induk 2,3,5,dan 6 memiliki rataan bobot sapih yang tidak jauh berbeda yaitu (6.36), (6.93), (6.74), (6.26), sedangkan rataan bobot sapih yang tertinggi itu ada pada induk 7 dengan rataan bobot sapih per ekor adalah 7.54 $\mathrm{kg}$ /ekorrataan bobot sapih yang paling rendah itu terdapat pada induk 1 dan 8 , dengan bobot sapih per ekor 4.90 dan 5.15 kg/ekor. Bobot sapih per ekor ini masih lebih rendah dibandingkan dengan yang direkomendasikan oleh NRC (1998) yaitu sekitar 13-18 kg.Jadi berdasarkan hasil penelitian bobot lahir dan bobot sapih memiliki kolerasi yang sangat kecil yaitu 0.259834. Bobot sapih sangat ditentukan, antara lain oleh jenis kelamin, bobot badan induk, umur induk, keadaan saat ternak lahir, dan kemampuan induk menyusui anaknya, kuantitas dan kualitas ransum, serta suhu lingkungan Sihombing (2006).

\section{Mortalitas anak babi}

Persentase mortalitas atau kematian anak babi terlihat pada Tabel 6. Pada Tabel 6 dapat dilihat angka mortalitas anak babi dari saat anak babi dilahirkan sampai pada penyapihan terjadi mortalitas

Tabel 6. Persentase mortalitas anak babi dari masig-masing induk/minggu

\begin{tabular}{ccccc}
\hline \multicolumn{5}{c}{ Persentase (\%) Mortalitas Anak Babi dari Beberapa Induk/minggu } \\
\hline INDUK & M1 & M2 & M3 & M4 \\
\hline 1 & 0 & 21.42 & 0 & 0 \\
2 & 0 & 0 & 0 & 0 \\
3 & 0 & 0 & 0 & 0 \\
4 & 0 & 0 & 0 & 0 \\
5 & 10 & 0 & 0 & 0 \\
6 & 0 & 8.33 & 0 & 0 \\
7 & 0 & 0 & 0 & 0 \\
8 & 0 & 0 & 0 & 0 \\
\hline
\end{tabular}


pada induk 1, 5 dan 6 terjadi mortalitas yang berbeda yaitu mortalitas tinggi pada induk ke 1 dan terjadi pada minggu ke 2 dengan jumlah mortalitas adalah $21.42 \%$, sedangkan induk 5 memiliki angka mortalitas yang lebih rendah yaitu $10 \%$ dan $8.33 \%$. Persentase mortalitas yang terjadi dalam penelitian ini adalah 29.75 $\%$.Sihombing (2006) bahwa persentase mortalitas anak babi 20-25 \%.Mortalitas anak babi berhubungan dengan bobot lahir anak babi. Bobot lahir yang tinggi maka daya tahan hidupnya akan semakin baik. Eusebio (1980) menyatakan bahwa semakin tinggi bobot lahir anak babi maka daya tahan tubuh akan semakin meningkat dan anak babi mempunyai kesempatan yang besar untuk bertahan hidup.

Mortalitas pada anak babi terjadi disebabkan manejemen kandang, seperti penanganan induk dan anak babi,sejak dari anak babi dilahirkan sampai pada waktu akan disapih kurang baik. Sifat dari induk babi atau keibuan dari induk babi sangat berpengaruh terhadap angka mortalitas karena pada saat induk akan berbaring ada anak babi yang ditindihnya. Selain itu juga disebabkan oleh anak babi yang terkena penyakit seperti (mencret) anak babi biasanya kedinginan, sehingga menjadi lemes dan sulit untuk menkonsumsi air susu dari induk babi, sehingga terjadi kematian pada anak babi itu sendiri.
Hurley (2001) menyatakan bahwa angka mortalitas yang terjadi lebih dari $60 \%$ disebabkan oleh faktor induk dan pengaruh dari rendahnya produksi susu dari induk. Davidson (1949) menyatakan bahwa dari hasil pengamatan $18,1 \%$ dari anak lahir mati selama periode menyusu, ditindih oleh induk 48,7 \%, perawatan yang kurang baik 22,1\%, diare 9,1\% dan yang kekurangan susu $8 \%$, kurang darah dan kedinginan 5,2\%, di gigit induk 1,9\% dan kecelakaan lain 1,3\% dan tidak di ketahui sebabnya $3,7 \%$, kematian ini kebanyakan terjadi pada periode berbahaya 3 hari setelah anak babi dilahirkan.

Suatu hasil survey juga melaporkan Anonimous (1966) bahwa kematian anak babi hingga 8 minggu adalah 25,9\%,6\% diantaranya mati lahir dan $15 \%$ mati selama seminggu pertama. Lagetes, (1972) menambahkan bahwa mortalitas berpengaruh pada kelangsungan dari bobot lahir sampai di sapih.Hartsock (1974) meneliti bahwa berat lahir anak babi berhubungan dengan kematian anak babi. Smith (1937) anak babi yang terbanyak dari setiap kelahiran adalah kecil-kecil dan yang terkecil adalah yang terlemah. Loveday (1966) menyatakan bahwa kematian anak babi per kelahiran umumnya sekitar $20 \%$ dan $80 \%$ mati selama minggu pertama. 
Menurut Bolet (1982) tingkat mortalitas anak babi sebelum disapih dapat mencapai $72 \%$ dengan penyebab utamanya $35,4 \%$ akibat terinjak oleh induk, 14\% akibat kaki tidak lurus, $11 \%$ akibat agalactia dan $11,6 \%$ akibat kelemahan anak-anak babi pada waktu lahir dan hal ini sering terjadi pada induk yang beranak pertama kali. Selain itu faktor penyakit yang disebabkan oleh virus dan bakteri serta kurang manajemen dapat meningkatkan kematian anak babi sebelum di sapih.

\section{KESIMPULAN}

Berdasarkan hasil penelitian dapat disimpulkan bahwa bobot lahir anak babi, menentukan seberapa besar litter size, bobot sapih, PBB, dan mortalitas. Semakin besar bobot lahir semakin besar kemungkinan memperoleh bobot sapih yang tinggi seperti dalam penelitian ini bobot lahir tertinggi yaitu $1.64 \mathrm{~kg}$ setelah di sapih mencapai bobot $7.54 \mathrm{~kg}$.

\section{DAFTAR PUSTAKA}

Anonimous. 1966. A Survey of te incidence and causes of mortality in pigs. In progress in Swine Practice. American Veterinary Publication Inc California.
Anggorodi, R. 1994. Ilmu Makanan Ternak Umum. PT Gramedia Pustaka Umum, Jakarta.

Anggorodi HR. 1995. Nutrion Ternak Unggas. Edisi Pertama. Jakarta . Penerbint PT Gramedia Pustaka Utama

Bolet, G. 1982. Analysis of cause of piglet mortality before weaning. Influence of GeneticType and Parity. Anim. Breed. Abstr. 50 (11).

Davidson, H.R. 1949. The Production and Marketing of Pigs. Longmans, Green and Co. Londo - New York -Toronto.

De Borsotti, P.N.,O. Varde and D. Plasse. 1982. Genetic and environmental factor affecting growth of. Piglets. Amim. Breed. Abstr. 50 (12).

Dziuk PJ. 1992. Embryonic development and fetal growth. Anim Reprod Sci 28:299-308.

Eusebio JA 1980. Ping Production and The Tropics. Intermediate Tropical Agriculture Series. Logman Group Ltd. Hong Kong. Pp 7-26.

Gordon, I. 2008. Controlled production in Pigs. CAB internasional, Washington DC.

Hartsock, T.G. and H.B. Graves. 1974. Effects of neonatal behavior on piglet mortality.J. Anim. Sci. 39 (1) : 135 (abstr). 
Hurley WL,. 2001. Mammary gland growth in the lactating sow. Livestock Prod Sci 70: 149-157.

Inglis LK. 1980. To Laboratory Animal Science and Technology. Program Press Ltd., Oxford.

Lagetes, J.E. 1972. The Role of maternal Effects in Animal Breeeding : IV, Maternal Effects in Laboratory Species. Jurnal of Animal Science. 35 (6): 1294-1302.

Lawlor, P.G., Amel P.B. Lynch 2007. A. Review of factors Influencing Litter Size in irish sows. Irish Vaterinary Jurnal 60 (6) : 359366.

Loveday, R.K. 1966, Management of new born pigs. In progress in swine Practice. American Veterinary Publication In. California.

(Natonal Research Council). 1998. Nutrition. Butterworth Heineman. Stoneham. USA.
Pardosi U. 2004. Pengaruh Perkawinan antara tiga bangs babi terhadap prestasi anak babi dari lahir sampai dengan di sapih di PT. Mabarido Sumbal multiform. Tesis Fakultas Petsernakan Universitas Diponegoro. Semarang.

Pond, W.G.and J. H. Maner. 1974. Swine Production In Temperate and Tropical Environments.W.H. Freeman and Company. San Fransisco.

Sihombing DTH. 2006. Ilmu Ternak Babi. Cetakan ke 2. Gadjah Mada University Press, Yogyakarta

Smith, W.W.1937. Pork Produktion.Revised Edition The Macmillan Company, New York.

Toulihere, M.R. 1985. Insiminasi Buatan pada ternak Penerbit Angkasa, Bandung. 